\title{
Nykytaiteen osallistavat opetukset
}

\author{
RIIKKAHAAPALAINEN
}

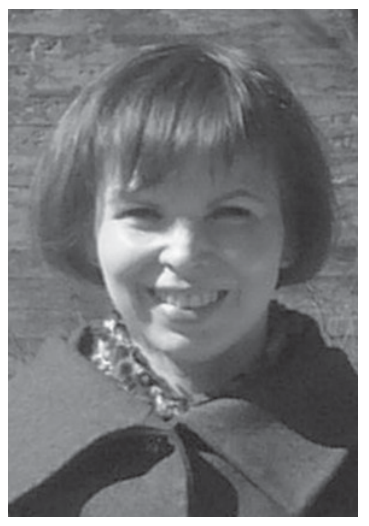

"Moniarvoisessa ja -mutkaisessa maailmassa "paras" taideteos ei välttämättä olekaan sellainen, jota olisi helppo tai nautinnollista katsoa tai jonka ehdottaman maailmankuvan ja ihmiskäsityksen voisi itse täydellisesti hyväksyä. Keskeistä ei ole enää se, miltä teos näyttää tai mikä sen esteettinen arvo tai merkitys on. Tärkeää on se, miten taideteos puhuttelee, luo suhteita ja kohtaa katsojan", kirjoittaa Riikka Haapalainen.
$\mathrm{V}_{\mathrm{i}}$ iimeisen sadan vuoden aikana kuvataide on muuttunut nopeammin kuin käsitykset siitä. Erityisesti kaksi määrettä taiteen arkipuheessa on ollut ja pysynyt: tosi taide on yksilöllistä ja vapaata.

Individualismi ja autonomisuus taiteen arvoina heijastavat aikaa, jolloin taide oli erityisesti vain taidetta varten ${ }^{1}$. Modernistinen taide jatkoi romantiikan sinetöimää myyttiä taiteilija-poikkeusyksilöstä, joka pidäkkeettömästi luo ja ilmaisee itseään taiteessaan. Myös taiteen tuli irrottautua tavanomaisesta ja sisällöistä, jotka viittasivat muualle kuin taiteeseen itseensä. Siten modernismi jaotteli ihmiset taidetta ymmärtäviin asiantuntijoihin sekä maallikoihin, joilla ei ollut sisäsyntyistä makua käsittää taidetta (Lippard 1984, 74). Ajattelutapa hyväksyi sen, että taide ei avaudu - eikä sen edes kuulu avautua - jokaiselle ilman erityisiä välineitä: koulutusta.

Modernistisen taideteoksen tunnisti taatusti taiteeksi kun sen kohtasi. Erityisesti varhaiset avantgardistit edellyttivät taiteelta sokkia ja jopa julmuutta katsojaa kohtaan. Taiteen tuli ravisuttaa yhteiskunnan luutuneita rakenteita räväyttämällä kaikki elämän epäkohdat päin katsojaa. Taiteen vastaanottoprosessi oli yksisuuntainen. Ensin taiteilija loi teoksen, asetti sen näytteille, minkä jälkeen oli katsojan vuoro reagoida teoksen sanomaan ja taiteilijan intentioihin.
Taide sisälsi olettaman, että taiteilija tallentaa teokseen merkityksen, joka on katsojan nostettavissa yksilöllisen kontemplaation kautta. Katsoja seisoo teoksen edessä ikään kuin se olisi tehtävä, joka pitäisi ratkaista. ${ }^{2}$ Ajatus siitä, että taiteilija sijoittaa taideteokseensa tiettyjä ominaisuuksia intentionsa - katsojan tulkinnan tärkeimmäksi pohjaksi muistuttaa Paulo Freiren kritisoimaa kasvatuksen talletuskäsitystä, jonka mukaan opetuksessa oppilaiden roolina on vain vastaanottaa ja arkistoida opettajan heihin tallentama tieto (Freire 2005(1968), 75-93).

Freiren lanseeraamassa kriittisessä pedagogiikassa on paljon yhteistä nykytaiteessa viime aikoina entistä enemmän tilaa saaneelle osallistavan taiteen $^{3}$ päämäärille. Osallistava taide laajentaa katsojan roolia perinteisestä kontemplatiivisesta vastaanottajasta aktiiviseksi taiteen toteutumiseen osallistuvaksi toimijaksi.

Jos taide erkaantui modernismin seurauksena elämästä, eristi modernin yhteiskunnan yksilökeskeisyys myös yksilöt toisistaan. Osallistava taide tarjoaa yhdenlaisen vastalauseen modernisaatioprosessissa syntyneille vieraantumisen ja välinpitämättömyyden kokemuksille. ${ }^{4}$ Sen pyrkimyksenä on tuoda toisistaan vieraantuneet ihmiset yhteisen kokemisen alueelle. Kyse on uuden kollektiivisen yhteisyyden löytymisestä, jossa taiteen 
erityisyys ei välttämättä palaudu teoksen puhtaaseen estetiikkaan: siihen miltä teos näyttää. Keskeisempää on se, miten teos vaikuttaa arjessa sekä se, minkälaisia kommunikatiivisia suhteita se ympärilleen luo. (Haapalainen 2006).

Taiteen muuttuneet käytännöt sekä haastavat "klassiset” tavat luokitella ja ymmärtää taidetta että hämärryttävät taiteen ja muun elämän rajoja. Siksi katse on siirtymässä taiteen yksilöitä kehittävästä oppimistehtävästä siihen, minkälaista muutosta taiteen vuorovaikutusta ja seurallisuutta painottavissa käytännöissä voi syntyä.

\section{Arkinen taide}

Jos taide pyrki läpi modernismin historian vaikuttamaan yhteiskunnan ja arjen ulko- ja yläpuolella, on osallistavan taiteen suunta päinvastainen. Se edustaa paremminkin elämää taiteen ja taidetta elämän vuoksi -ajattelua, jossa taide kietoutuu joka päiväiseen ja pyrkii omalla logiikallaan näyttämään tai ainakin riittävän uskottavasti muistuttamaan arkea. Kovin arkiselta vaikuttaakin, kun esimerkiksi Rirkrit Tiravanija kutsuu taideyleisönsä näyttelytiloihin pelaamaan, nukkumaan tai laittamaan ruokaa. Tai kun Tellervo Kalleinen ja Oliver Kochta-Kalleinen keräävät kaupunkilaisia sanoittamaan, säveltämään ja esittämään kuorossa laulun arkisista valituksenaiheistaan. Leikillinen yhdessäolo, oman itsen ylittäminen, ennakoimattomuus ja sattumanvarainen kohtaaminen saavat sijaa. ${ }^{5}$

Taiteen liitto arjen kanssa muuttaa näkökulmia sekä katsojuuteen että taiteilijuuteen. Taiteen vastaanottotilanne ei ole enää sosiaalisesta irrallinen, autonominen saareke ${ }^{6}$, jonka toimintalogiikka olisi merkittävästi toisenlainen kuin muun elämän. Samalla kun katsojan rooli osallistavassa taiteessa aktivoituu ja laajenee, luopuu taiteilija osin siitä symbolisesta vallasta, joka tällä on perinteisesti ollut taideteokseen, katsojaan ja taidemaailmaan nähden. Osallistavassa taideteoksessa tämä taitelijan valta on edelleen läsnä, mutta kohdentumattomampana ja aineettomampana; taiteilijan paikka on olla yksi monista, ei erityisasemaan oikeutettu sankari. Tämä roolimuutos tarkoittaa sitä, että taiteilija ei vain luo taideteoksia, vaan on ennen kaikkea tilanteiden ja kontekstien alullepanija, katalysaattori.

Osallistavassa taiteessa saatetaan hyödyntää taidelähtöisiä menetelmiä, poikkitieteellistä sovelluskenttää ja esimerkiksi harrastus- ja viriketoiminnasta tuttuja vuorovaikutuskeinoja. Siten se kol- kuttelee ja koettelee perinteisen taidejärjestelmän ja -tulkinnan rajoja. Monet postmodernin teoreetikot ajattelevatkin, että kiinnostavaa ajattelua voi syntyä vain erilaisten prosessien ja välineiden välissä olemisesta. Tähän viittaa myös osallistavan taiteen hybridiys: ollaan niin paljon kaiken välissä, että lopulta ehkä ollaankin kaiken ehdottomassa keskiössä.

Osallistava taide on astunut ulos taiteen perinteisistä esittämispaikoista, museoista ja gallerioista. Ei ole mitään tiettyä tai ennalta sovittua taiteen paikkaa, vaan taide saattaa kehittyä alueella, jota perinteisesti on luonnehtinut työ ja tuotanto. Kaikkialle levittäytyvässä taiteessa ei enää korostu konkreettiset taideteokset vaan niiden aineettomampi olomuoto. Taiteesta on tullut keinoja, vuorovaikutusta ja menetelmiä, joilla siirtää katsoja teoksen vastaanottajasta tai osallistujasta tilanteeseen, jossa teos on ja tapahtuu, ja joilla aktivoida katsojan suhde maailmaan.

Kun taide ei enää rajaudu johonkin selkeään lopputuotteeseen, kuten esimerkiksi näyttelyyn, taideteokseen tai oikeaan tulkintaan, jäljelle jää kommunikatiiviset käytännöt. Tilanteiden taiteessa keskiössä on vaihto: taide tuo erilaisia ihmisiä yhteen jakamaan ja vaihtamaan ajatuksiaan, aikaansa ja tunteita ${ }^{7}$. Tilannesidonnaisuus "vapauttaa” taiteilijan kuvaamasta ja representoimasta maailmaa: hän voi siirtyä taiteen ja representaation sisäisistä kysymyksistä ulos yhteiskunnalliseen vaikuttamiseen.

\section{Joka-aikuisen luovuus}

Saksalainen shamaanitaiteilija Joseph Beuys tunnusti katsojan kyvyn tuottaa merkityksiä taiteesta ja uskoi vapaaseen - ilmaiseen ja riippumattomaan - koulutukseen. Hänen mukaansa jokaisella ihmisellä on voima ja kyky muuttaa maailmaa, sillä "Jedermann ist ein Künstler" (Jokainen on taiteilija). Tämä jokaiselle kuuluva luovuus toteutui sosiaalisuudessa: Beuysin yhteiskunnallisen muutoksen väline oli "sosiaaliset veistokset”, joita hän muovasi erilaisissa performatiivisissa tilanteissa, keskusteluissa ja kohtaamisissa. Hän laajensi toiminnallaan taidekäsitystä yli eriytyneen ja erikoistuneen toiminnon päämääränään ihmisten tietoisuuden muutoksen kautta tapahtuva arjen muutos. ${ }^{8}$

Ranskalaiselle sosiologi Michel Maffesolille luovuus ei merkitse uusien asioiden keksimistä, vaan sen löytämistä mitä jo on; jo tulollaan olevan tuomista esille. (Gaillot 1998, 106). Hänen mukaan- 
sa taide ei siten tarjoa eskapismia, pakoa tästä maailmasta ja sen mutkikkuuksista. Taide ei silitä myötäkarvaan, eihän maailmakaan tee niin.

Päinvastoin, taide ja luova toiminta ei ole vain 'hyvää' tekevä voima. Se voi yhtä lailla toimia koneistona myös 'pahalle'. Esimerkiksi Claes Andersson (2002) on kuvannut luovuuden toista puolta, tuhoisaa ja hajottavaa mahtia. Luovaa prosessia ei voi määrätä tapahtuvaksi eikä sen suuntaa voi loppuun asti hallinnoida. Luovuus ei ole projekti vaan jatkuva prosessi, joka vaatii kehittyäkseen ennen kaikkea tilaa ja aikaa. Siten taide edellyttää hitautta ja tavoitteetonta, pitkäaikaista prosessointia; tyhjäkäyntejä. Ja siksi taiteen osallistavat käytännöt on paalutettu monien epävarmuuksien päälle: niiden lopputulosta - taiteellista tasoa tai osallistujien luovaa panosta - on mahdotonta ohjata.

Siten osallistavan taiteen päämääränä korostuu muutoksen hallinnan sijaan tilanteiden ja paikkojen tarjoaminen yhdessäoloon ja kohtaamisille. Osallistavan taiteen utopia ei voi olla ennalta määritellyissä, kiinteissä paremman maailman toivekuvissa, vaan liikkeelläolemisessa, vuorovaikutteisessa vaihdossa ja mahdollisuuksissa. Itse muutoskin on usein henkilökohtaista ja satunnaista ei suurta vallankumousta tai kulttuurista ja poliittista muutosta, jollaista esimerkiksi 1960-luvun edistysuskossa taiteella tuotettiin.

\section{Epävarma yhteisöllisyys}

On annettua, että elämä ja ihmiset ovat monimutkaisia ja -ulotteisia. Siksi luovalle prosessille, sattuman säätelemille tilanteille ja aidolle vuorovaikutukselle antautuminen merkitsee taiteelle vääjäämättä epävarmuudessa elämistä ja keskeneräisyyden hyväksymistä: taiteilija hylkää oman itseilmaisun varmuuden ja kontrollin ja vaihtaa sen tilalle ihmisten välisen epävakaan yhteistoiminnan.

Yhteisöllisen taiteen osallistujina voi olla mitä moninaisimpia ihmisryhmiä ja yhteisöjä, toiset pysyviä, toiset hyvin löyhästi yhteen liittyneitä; toiset ennestään tuttuja, toiset tuntemattomia. ${ }^{9}$ Osallistavia projekteja on tehty eri ammattiryhmien, kulttuurivähemmistöjen, vammais- ja muiden erityisryhmien kuin niin sanottujen tavallisten ihmistenkin parissa.

Yhteisöllinen Villa Nova -taide- ja taidekasvatusprojekti (2006) on esimerkki osallistavasta taideprojektista, jonka kohteena oli poikkeuksellisen haasteellinen erityisryhmä, moninkertaisesti syrjäytyneet - asunnottomat ja päihdeongelmaiset - miehet. Projektin tavoitteena oli synnyttää yhdessä miesten kanssa ympäristötaideteos heidän asukasyhteisönsä pihapiiriin Myllypuroon. (Kontusalmi 2007.)

Projektin taiteellisesta osasta vastannut Forest Camp -taiteilijakollektiivi ryhtyi toteuttamaan hanketta tunnustaen yhteisön haasteellisuuden ja soveltaen "joustavuuden teoriaksi” nimettyä toimintaperiaatetta. Jotta teos syntyisi aidosti päihdeongelmaisten miesten ehdoilla, taiteilijat pyrkivät hienovaraisesti soluttautumaan hienovaraisesti osaksi yhteisön arkea. Ryhmä grillasi makkaraa, kulutti vapaa-aikaa, turinoi ja tuunasi hirsikalusteita miesten kanssa. Kokoontumisten yhtenä lopputulemana oli pihamaalle pystytetty taideteos. Taideteosta tärkeämpi tulos oli onnistumisen kokemusten syntyminen - ainakin projektiin osallistuneille miehille, joiden elämänhistoriaan oli sisäänkirjoitettu rauenneiden mahdollisuuksien kierre.

Jos Villa Nova -projekti tuotti ainakin hetkeksi katkoksen miesten elämän epäonnistumisten sarjaan, voi positiivisen muutoksen vastavoimana olla yhteisöjen essentialismi ja sosiaalisten sisältöjen niin sanottu "helppo vaihto" (Kwon 2004, 146147). Aidon muutoksen sijaan projektit saattavat vain vahvistaa osallistujien omaa identiteettiä ja vallalla olevia käsityksiä, jolloin totuttuja ja helppoja ajatus- ja toimintamalleja ei kyetä haastamaan.

\section{Taiteen kytkykaupat}

Monille osallistavan taiteen projekteille on leimallista sosiaalisen muutoksen työ. Erityisesti Pohjois-Amerikassa taiteilijat ovat vahvasti toimineet erilaisten asioiden puolestapuhujina ja auttajina ilman, että heidän toimintaansa välttämättä nimettäisiin taiteeksi: tärkeämpää on ollut teon poliittisuus ja auttaminen. ${ }^{10}$ Osallistavan taiteen taustalta ei kuitenkaan välttämättä löydy eksplikoitua yhteiskunnan tavoitetilaa, jonne ohjelmallisesti tai järjestelmällisesti tähdättäisiin - kaikki taiteilijat eivät edes pyri opettamaan tai tuottamaan muutosta, vaikka sellaista taiteen sivutuotteena syntyisikin.

Jos avantgarde aiemmin loi ja valmisti tulevaisuuden maailmaa, nykyään se muokkaa ja hahmottaa mahdollisia maailmoja. Siten osallistavan taiteen oppimistehtävä ei ole tavoitella utooppisia eli perusluonteeltaan kuvitteellisia yhteiskuntajärjestelmiä, vaan olla elämäntapoina ja toimintamalleina ympäröivässä todellisuudessa - vahvistaa tunnetta ja kokemusta maailmasta. Taide voi tuo- 
da näkyviksi ne ääripäät, joille todellisuus rakentuu. Kun erilaisuudet tehdään näkyviksi, ne menettävät dogmaattiset painoarvonsa ja nousevat - potentiaalisesti - synnyttämään uudenkaltaista suvaitsevaisuutta. Taiteen päämääristä tulee elämän päämääriä.

Jos kriittisen pedagogiikan teoriaperinne pyrkii tuottamaan muutokselle moraalisen ja eettisen sisällön määritellessään muutoksen tietona siitä, miten asioiden pitäisi olla pyrkiessään kasvattamaan tasavertaisuutta yhteiskunnassa, osallistavassa taiteessa ei välttämättä etukäteen määritellä muutoksen laatua tai suuntaa. Taide ei vain kuvasta tai heijasta ympäröivää maailmaa - ole kuva siitä - vaan se voi tuottaa ja tarjota uutta tietoa ihmisistä itsestään ja yhteiskunnasta jossa elämme. Taide voi tuottaa uutta tietoa, joka on sovellettavissa myös muualla yhteiskunnassa.

Moniarvoisessa ja -mutkaisessa maailmassa "paras” taideteos ei siten välttämättä olisikaan sellainen, jota olisi helppo tai nautinnollista katsoa tai jonka ehdottaman maailmankuvan ja ihmiskäsityksen voisi itse täydellisesti hyväksyä. Hyvän sisältöä koskevassa arvovaihtoehtojen maailmassa moraalisista ja esteettisistä ongelmista on tullut vuorovaikutuksen, kohtaamisen ja argumentoinnin kysymyksiä. (Rantala 2001, 20). Samalla tavalla taiteella ja totuudella ei ole enää tiukkaa kohtalonyhteyttä: hyvä taide voi kertoa myös valheellisista ja moraalisesti ongelmallisista asioista. Tämän moraalisen hyvän "suhteellistumisen” voi taiteessa ymmärtää siten, että keskeistä ei ole enää se, miltä teos näyttää tai mikä sen esteettinen arvo tai merkitys on. Tärkeää on se, miten taideteos puhuttelee, luo suhteita ja kohtaa katsojan. (Haapalainen 2007b.)

Kun yhteisötaiteesta tuotetaan entistä tietoisemmin ja järjestelmällisemmin yhteiskuntaa muuttava ja muokkaava toimintamuoto, eivät sen perinteiset ominaislaadut - yhdessä tekeminen ja jakaminen - enää 'riitä'. Taide voidaan kiinnittää suoraan valtiota ja yhteiskuntaa hyödyntäviin päämääriin, jotka eivät lähtökohtaisesti ole taiteen päämääriä.

Esimerkiksi suomalaiseen hyvinvointipolitiikkaan on sisäisten uusiutumispaineiden edessä haettu uutta sisältöä taiteesta ja kulttuurista. Taiteesta on muokattu sosiaalipoliittinen väline, jolla torjua sekä kansalaisten syrjäytymistä että edistää alueellista hyvinvointia. Erityisesti sosiaali- ja terveysalalla on puhuttu niin sanotusta soveltavasta taiteesta tai taidelähtöisestä kehityssuun- nasta sellaisten taideprojektien kohdalla, joissa taide on kuljetettu sinne missä ihmiset arkeaan elävät: työpaikoille, kouluihin ja päiväkoteihin tai esimerkiksi hoitolaitoksiin. Taiteen soveltavaa käyttöä perustellaan sen kansalaisuuteen kasvattamisen ja hyvää tekevillä ominaisuuksilla: taide voi parantaa ja pidentää elinikää; taide eheyttää ja voimauttaa. ${ }^{11}$

Alueellisen kilpailukyvyn ja vetovoiman lisäämisessä on myös huomattu taiteen noste. Esimerkiksi Tuula Isohannin koordinoimana Helsingin uudelle Arabianrannan asuinalueelle 2000-luvulla sijoitettujen puolijulkisten taideteosten tarkoitus on lisätä asuinympäristöön "hyvää” siinä luottamuksessa, että taide parantaa elinpiiriä ja laadukas elinpiiri lisää asukkaidensa terveyttä ja hyvinvointia (ks. Isohanni 2006; Haapalainen 2007c.)

Niin sanotulla prosenttiperiaatteella ${ }^{12}$ rahoitettua Arabianrannan taideohjelmaa on perusteltu taiteen ulkopuolisilla oppimistehtävillä: taide tekee Arabianrannasta "virikkeellisen" ja "elämyksellisen" paikan, jossa mm. voi "opetella eri asuntoyhtiöiden ja asukkaiden välistä kanssakäymistä”. Taide muuttaa kasvottoman asuinalueen yhteisen huolenpidon ja vuorovaikutuksen paikaksi, jossa asukkaille syntyy halu kantaa vastuuta omasta lähiympäristöstä ja sen viihtyisyydestä. (Isohanni 2006). Taide on valjastettu palvelemaan hyvän ja omaleimaisen kaupunkiympäristön ja alueellisen menestyksen ${ }^{13}$ pyrkimyksiä.

Kun kulttuurista haetaan menestystä, kyseenalaistuu taiteen eettinen vapaus. Esimerkiksi uusliberalistisen kielenkäytön ja argumentaation rantautuminen taiteeseen tämänkaltaisten pyrintöjen oheistuotteina saattaa tuottaa taiteeseen vaateita, jotka johtavat juuri taiteen voiman laimentamiseen ja varman päälle toimimiseen. Jos esimerkiksi taiteelta edellytetään selkeätä, määrällisesti mitattavaa vaikuttavuutta, ohittuu taiteen oma laadullinen ominaislaatu pitkäaikaisine ja kohdentumattomine vaikuttavuuksineen sekä heikkoine signaaleineen. (Podesva 2007, ks. myös Haapalainen 2007a, Eräsaari 2006.)

\section{Taiteen kasvatuksellinen käänne}

Vaikka nykytaiteessa taideteoksen ja sen ehdottaman sisällön kasvatuksellinen suhde ei ole näkyvä tai suora, on viime aikoina puhuttu nykytaiteen kasvatuksellisesta käänteestä (Podesva 2007, Rogoff 2008): moni kuraattori ja taiteilija soveltavat 
toiminnassaan kouluista, lukupiireistä, luennoilta ja laboratorioista lainattuja välineitä ${ }^{14}$ taiteensa tuottamiseen jopa siinä määrin, että toisinaan on toiminnan ulkoisista piirteistä vaikea tunnistaa, onko kyseessä taidekasvatus vai taiteilijan ohjaama taideteos. Pohja taiteen kasvatukselliselle käänteelle on nähty muun muassa Nicolas Bourriaudin hahmottelemassa relationaalisessa estetiikassa ja instituutiokritiikissä.

Nicolas Bourriaud (2002, 14-15) kuvailee, kuinka moderniteetin synnyttämä urbaani kulttuuri on laajentanut ja muuttanut kaikkia kulttuurisia ilmiöitä. Hänen mukaansa myös taiteellinen kokeilu on urbanisoitunut. Se on saanut piirteitä sosiaalisista vaihdoista ja yksilöiden liikkuvuudesta. Nykytaide ei enää toimi tilassa, jonka läpi kuljetaan (vrt. museoiden kokoelmaripustukset tai gallerianäyttelyt), vaan se koetaan tietyssä aikaperiodissa, jonka läpi eletään ikään kuin keskusteluun avautuen. Niin kuin kaupungissa ihmiset asettuvat alttiiksi kohtaamisille ja vuorovaikutuksille, myös taiteellisen toiminnan keskeisenä teemana on yhdessäolo (ks. myös Mäenpää 2005). ${ }^{15}$

Instituutiokriittinen asenne perustuu huomiolle siitä, että perinteisen taidenäyttelyn staattinen muoto ei enää vastaa taiteen uutta etsivää ja prosessimaista luonnetta. Uutta viitekehystä, paikkaa jossa kehittää kriittisiä toimintatapoja, on etsitty koulutuksen puolelta. Saattavathan koulut ja oppilaitokset olla niitä harvoja paikkoja, joissa edelleen kannustetaan - ainakin heikossa mielessä kokeiluihin; joissa toiminnan painopiste on lopputuotteen sijaan prosessissa ja oppimisessa. (Vidokle 2008.)

Irit Rogoff (2006) on verrannut taiteen paikkoja ja oppimisen paikkoja ja löytänyt niistä paljon samankaltaisuuksia. Samoin taiteen käytännöt tuntuvat kulkevan rinnakkain oppimisteorioiden kehittymisen kanssa. Puhutaan yhteisöllisestä ja tilannesidonnaisesta oppimisesta siinä missä puhutaan yhteisöllisestä ja tilannesidonnaisesta taiteestakin. Tosin kasvatustieteen käytännöt ovat tavoiterationaalisempia ja niiden synnyttämä muutos ohjatumpaa ja sanallistetumpaa, kun taas taide on prosessikeskeisempää. Avoimuus erilaisille mahdollisuuksille - spekulaatioille ja kokeiluille voisi olla taiteen ydin tiedontuotannon sijaan.

Aikuisille suunnattu taidekasvatus on ollut tyypillisimmillään normatiivista asiantuntijapuhetta: opastuksia, näyttelykierroksia, luentoja. Nämä kaikki ovat esimerkkejä yksilön oppimisesta (ks. Haapalainen 2004). Taidekasvatuksen teemat ovat pää- sääntöisesti käsitteellisiä: on tutkittu ajatuksia, käsitteitä ja ilmiöitä. Tätä teoreettis-kognitiivispohjaista toimintaa on kritisoinut esimerkiksi Barbara Bolt (2006), jonka mukaan silmillä ja käsillä työstäminen tarjoaa toisenlaista tietoa maailmasta kuin teoreettis-kognitiivinen toiminta. Hän perustaa ajatuksensa Martin Heideggerin taidefilosofiaan, jonka mukaan tieto - suhteemme maailmaan - nousee materiaaleista ja prosesseista, tekemällä ja käsittelemällä.

Instituutiokritiikki tuo esille muun muassa taidemuseoiden oman tiedostuksen esillepanon vallankäytöstä ja museoista tiedontuotannon paikkoina. Näitä vallankäytön malleja ovat näyttäneet performatiivisin ja pedagogisin menetelmin museot itse sekä taiteilijat (Podesva 2007; KirshenblattGimblett 2000). Suomessa esimerkiksi kuvataiteilijat Hannele Rantala ja Elina Saloranta ovat taiteellisten interventioidensa sarjassa kyseenalaistaneet taide- ja kulttuurihistoriallisten museoiden tapaa esittää ja luokitella esineitään.

Instituutiokriittinen pedagoginen ote kannustaa ja rohkaisee yksilöitä seuraamaan omia mielenkiinnon kohteitaan: avautumaan teokselle ja sen ehdottamalle maailmalle ja täydentämään sen omalla elämällään: yksilö muodostaa ja järjestää tietoa samalla kun oppii uutta. Oppimisteorioissa tämä muistuttaa paljolti George Heinin (2005) esittämää konstruktivistista oppimiskäsitystä, jonka mukaan ihminen rakentaa taide-elämyksensä ja -ymmärryksensä sen pohjalle, minkä jo tuntee ja tietää omakseen. Se huomioi kuvataiteen vastaanotolle luonteenomaisen syklisyyden ja dialogisuuden: merkitys rakentuu siirtymillä kokonaisuuden tarkastelusta yksityiskohtaan ja takaisin. (ks. esim. Hooper-Greenhill 1999, 44-48.)

Oppimisteorioiden mallintamassa yhteisöllisessä ja yhteistoiminnallisessa oppimisessa on paljon yhtäläisyyksiä taiteen käytäntöihin. Erot löytyvät - jos karkeasti yleistää - suhtautumisesta muutokseen. Oppimisen kontekstissa lähtökohtana on muutoksen ohjaus ja tiedolliset ja toiminnalliset tavoitteet. Muutos- ja kehityspaineet nähdään maailmaan sisältyvinä haasteina, jotka on kohdattava ja joihin on reagoitava. Yhdessä oppivan ryhmän on saattanut tuoda yhteen esimerkiksi sama ammatti, harrastus, asuinpaikka tai jokin muu yhteinen elämänala.

Taiteen synnyttämät yhteisöt ovat monesti sattumanvaraisempia ja lyhytkestoisempia. Oppimisen synnyttämä yhteisöllinen muutoskin on "epätuottavampaa”, ei mitattavissa olevaa kokemusta. 
Siksi taiteen lähtökohdista tapahtuva yhdessä oppiminen on luonteeltaan seurallista: sitä luonnehtii puhdas, pinnallinen yhdessäolo. ${ }^{16}$ Oppiminen on leikillistä, se pohjaa esimerkiksi improvisaatioon, tutkimiseen, olettamuksien tekoon, intuitioon ja assosiatiivisuuteen. Vastaanottotilanteen sisältö on enemmän elämystä kuin tietoa, tuntemista kuin tietämistä; tarinoita kuin esineitä.

Taiteen tarjoilemat lupaukset kulkevat kuitenkin aina konditionaalissa. Taide - oppimisen ja hyvinvoinnin lähettiläänäkään - ei toimi automaattisena elämänlaatua kohottavana ruiskeena. Taide tähtää muutokseen, mutta harvoin saavuttaa mitään "valmista”. Sille on leimallista tilanteiden avoimuus ja keskeneräisyys. Oppimisen jäljet näkyvät heikkoina, mutta voivat vaikuttaa vahvasti.

\section{Lähteet}

Andersson, C. (2004). Luova mieli. Kirjoittamisen vimma ja vastus. Helsinki: Kirjapaja.

Bardy, M., Haapalainen, R., Isotalo, M., Korhonen, P. (2007). Taide keskellä elämää. Nykytaiteen museo Kiasman julkaisuja 106/2007. Keuruu: Like.

Bishop, C. (2006). The Social Turn: Collaboration and its Discontents. Artforum. February 2006. http://www.artforum.com/inprint/id=10274 (luettu 13.4.2008)

Bolt, B. (2006). Materializing Pedagogies. Working papers in Art and Design 4. https:// www.herts.ac.uk/artdes/research/papers/wpades/vol4/bbfull.html (luettu 28.11.2008)

Bourriaud, N. (2002). Relational Aesthetics. Dijon-Quetigny: Les presses du réel.

Elkins, J. (1996). Why are Our Pictures Puzzles? Some Thoughts on Writing Excessively. New Literary History, 1996, 27.2, 271-290.

Eräsaari, L. (2006). New Public Management on julkista koskevien vääryyksien isä. Teoksessa T. Helne \& M. Laatu (toim.) Vääryyskirja. Helsinki: Kelan tutkimusosasto, 87-202.

Freire, P. (2005 (1968)). Sorrettujen pedagogiik$k a$. Tampere: Vastapaino.

Gaillot, M. (1998). Multiple Meaning Techno: An Artistic and Political Laboratory of the Present. Paris: Éditions Dis Voir.

Haapala, L. (1999). Taiteilijan muuttuva rooli yhteisötaidetta 90-luvun Suomessa. Katoava taide - Förgänglig konst - Ephemeral Art.
Toim. Leevi Haapala. Ateneum 1999. Helsinki: Valtion taidemuseo, 79-103.

Haapalainen, R. (2004). Kävijästä käyttäjäksi. Museopedagogian digitaalinen ulottuvuus. Teoksessa M. Levanto \& S. Pettersson (toim.).Valistus / museopedagogiikka / oppiminen. Taidemuseo kohtaa yleisönsä. Museologia-sarjan julkaisu 2, Helsinki: Valtion taidemuseo, Taidemuseoalan kehittämisyksikkö Kehys, 2004, 114-129.

Haapalainen, R. (2006). Contemporary Art and the Role of Museums as Situational Media. Journal of Visual Art Practice 5(3), 2006, 153-166.

Haapalainen, R. (2007a). Taide hyvinvointiyhteiskunnan uudistamisessa. Teoksessa K. Kivimäki ja H. Kolsio (toim.). Yhteyksiä. Asiaa yhteisötaiteesta. Lönnströmin taidemuseon julkaisuja 24. Tampere: Rauman taiteilijavierasohjelma Raumars ry, 72-81.

Haapalainen, R. (2007 b). Taidetta elämän vuoksi. Teoksessa M. Bardy, R. Haapalainen, M. Isotalo \& P. Korhonen (toim.) Taide keskellä elämää. Nykytaiteen museo Kiasman julkaisuja 106. Helsinki: Like, 221-226.

Haapalainen, R. (2007c) Täyttömaasta taidekeitaaksi - Tuula Isohanni Arabianrannan taiteellisena koordinaattorina. Yhdyskuntasuunnittelu, 2007: 1, 84-87.

Hautamäki, I. (2003). Avantgarden alkuperä. Modernin estetiikka Baudelairesta Warholiin. Helsinki: Gaudeamus.

Hein, G.E. (1995). The Constructivist Museum. Journal for Education in Museums, No. 16, 21-23.

Hiltunen, M. (2007). Pohjoista loistetta - Tulikettu ja muita taidetekoja. Teoksessa M. Bardy, R. Haapalainen, M. Isotalo \& P. Korhonen (toim.) Taide keskellä elämää. Nykytaiteen museo Kiasman julkaisuja 106. Helsinki: Like, 136-142.

Hooper-Greenhill, E. (1999). ”Learning in art museums: strategies of interpretation”, The Educational Role of the Museum. Toim. Eilean Hooper-Greenhill. Leicester Readers in Museum Studies, London: Routledge, 44-52.

Isohanni, T. (2006). Arabia Arabia. Taiteellinen toiminta osana asuinympäristön suunnittelua, tapaus Arabianranta, Helsinki. Taideteollisen korkeakoulun julkaisu A 66. Helsinki: 
Taideteollinen korkeakoulu.

Kirshenblatt-Gimblett, B. (2000). The Museum as catalyst. Keynote address, museums 2000: Confirmation or Challenge, organized by ICOM Sweden, the Swedish Museum Association and the Swedish Travelling Exhibition/ Riksutställningar, Sept 29, 2000. http:// www.nyu.edu/classes/bkg/web/vadstena.pdf (luettu 4.1.2004)

Kontusalmi, H. (2007). Elämäntarinat taipuvat taiteeksi. Teoksessa M. Bardy, R. Haapalainen, M. Isotalo \& P. Korhonen (toim.) Taide keskellä elämää. Nykytaiteen museo Kiasman julkaisuja 106. Helsinki: Like, 96-102.

Kwon, M. (2004). One Place After Another: Sitespecific Art and Locational Identity. Cambridge and London: The MIT Press.

Lippard, L. (1984). Get the Message? A Decade Of Art For Social Change. New York: E. P. Dutton, INC.

Maffesoli, M. (1995). Maailman mieli. Yhteisöllisen tyylin muodoista. Helsinki: Gaudeamus.

Mäenpää, P. (2005). Narkissos kaupungissa. Tutkimus kuluttaja-kaupunkilaisesta ja julkisesta tilasta. Helsinki: Tammi

Mäki, T. (2007). Yhteisötaide - tapausesimerkkinä Be Your Enemy Teoksessa M. Bardy, R. Haapalainen, M. Isotalo \& P. Korhonen (toim.) Taide keskellä elämää. Nykytaiteen museo Kiasman julkaisuja 106. Helsinki: Like, 232-241.

Oman, H. (1998). Joseph Beuys. Die Kunst auf dem Weg zum Leben. München: Wilhelm Heyne Verlag.

Podesva, K. L. (2007). A Pedagogical Turn: Brief Notes on Education as Art. The Filip Review, \# 6 Summer 2007. http://fillip.ca/content/apedagogical-turn (luettu 7.1.2009)

Rantala, K. (2001). ”Ite pitää keksii se juttu”. Tutkimus kuvataidekasvatuksen ja kasvatettavan kohtaamisista. Helsingin yliopisto, sosiologian laitoksen tutkimuksia nro 239. Helsinki: Yliopistopaino.

Rautio, P. (2006). Vastakohtien tavaratalossa ARS 06 kokemuksena. Valtion taidemuseo, Taidemuseoalan kehittämisyksikkö KEHYS. Julkaisematon tutkimusraportti.

Rogoff, I. (2006). Academy as Potentiality. Teoksessa Academy. Frankfurt am Main: Revolver.
Rogoff, I. (2008). Turning. e-flux 11/2008, Journal \# 0. http://www.e-flux.com/journal/view/18 (luettu 20.2.2009)

Sederholm, H. (1998). Starting to Play with Arts Education. Study of Ways tp Approach Experiential and Social Modes of Contemporary Art. Jyväslylä Studies in the Arts 63. Jyväskylä: University of Jyväskylä.

Siivonen, T. (1992). Avantgarde ja postmodernismi. Itsekritiikki ja radikalisoituminen modernissa taideinstituutiossa. Jyväskylän yliopisto, nykykulttuurin tutkimusyksikön julkaisuja 33. Jyväskylä: Jyväskylän yliopiston nykykulttuurin tutkimusyksikkö.

Simmel, G. (1964 (1950)). The Metropolis and Mental Life. Sosiology of Georg Simmel. New York: The Free Press.

Vidokle, A. (2008). Opening Remarks. Julkaisematon avajaispuhe, Night School, January 31, 2008, New Museum, New York.

\section{Viitteet}

1. Vrt. Taidetta taiteen vuoksi (L'art pour l'art) liike, josta enemmän esimerkiksi Siivonen (1992, 7-8) ja Hautamäki (2003, 80-83).

2. Tästä kirjoittaa enemmän James Elkins (1996), joka on verrannut tapaa lähestyä taideteosta palapelin tai arvoituksen ratkaisemiseen.

3. Käytän tässä artikkelissa osallistavaa taidetta ja yhteisötaidetta samaa ilmiökenttää kuvaavina termeinä: niissä molemmissa taiteen keskeisenä sisältönä on arkielämä ja erilaisten ihmisten välillä tapahtuva vuorovaikutus. Samoin monien osallistavien ja yhteisöllisten projektien ihanteena on taiteen ammattilaisten ja maallikoiden välinen tasaarvoinen yhteistyö (ks. esim. Mäki 2007, 232-233).

4. Artikkelissani keskityn ensisijaisesti luonnehtimaan osallistavaa taidetta. On kuitenkin huomioitava, että osallistavalla taiteella ja muilla nykytaiteen käytännöillä on paljon yhteistä - niin sisällöissä, tavoitteissa kuin vaikuttavuudessakin. Siksi paikka paikoin esiin nostamani osallistavan taiteen piirteet eivät juuri eroa muista nykytaiteen käytännöistä.

5.Katso lisää Valituskuoro-projekteista: www. ykon.org/kochta-kalleinen/complaintschoir.html 
6. Vrt. modernistisessa taiteessa vastaanoton ideaali oli kontemplaatiossa, hiljaisessa avautumisessa taiteeseen, joka muodoltaan muistuttaa uskonnollista kokemusta. Se sijaitsee erityisen alueella.

7. Ks. tämänkaltaisesta yhteisöllisyydestä enemmän, Maffesoli (1995).

8. Sosiaalisten veistostensa tukipisteeksi Beuys perusti vuonna 1973 vapaan yliopiston (Freie Internationalen Hochschule für Kreativität und interdisziplinäre Forschung), jossa taiteilijat, taloustieteilijät, psykologit ja muut ammattikunnat kohtaisivat, laajentaisivat taidekäsitystä ja edistäisivät sosiaalista muutosta. (Oman 1998, 86-90; 144 -145; Sederholm 2000, 43).

9. Taiteen yhteisölliseen osallistumiseen viittaa esimerkiksi Maffesoli (1993) korostaessaan postmodernin yhteisöllisyyden rakentumista satunnaisten, hajanaisten ja "pinnallisten" heimojen varaan.

10. Ks. esimerkiksi Haapala (1999, 83). Tätä asennetta erityisesti taidekriitikko Claire Bishop (2006) on kritisoinut siitä, että sosiaalinen vaikuttaminen on ollut ensisijaisempaa kuin taiteellisen laadun takaaminen.

11. Erilaisia tapausesimerkkejä taiteen soveltavasta käytöstä Suomessa työhyvinvoinnin edistämisestä maahanmuuttajien identiteettityöskentelyyn, katso Bardy et al (2007), katso myös Haapalainen (2007a).

12. Helsingin kaupunki on velvoittanut Arabianrannan rakennuttajia kohdentamaan prosentin tai kaksi rakentamiskustannuksista taiteelliseen yhteistyöhön.

13. Esimerkiksi tästä käy Lapin yliopiston yhteisöllinen taidekasvatushanke Tulikettu, jonka tavoitteena oli liittouttaa taide ja Lapin elämysmatkailu samaan päämäärään, tuottamaan hyvinvointia paikallisille elinkeinoille. (Hiltunen 2007.)

14. Ks. esimerkiksi italialaisen Michelangelo Pistoletton Unidee, ajatusten yliopisto Biellassa, Pohjois-Italiassa sijaitsevan teollisuuskaupungin kupeeseen perustetussa Cittadellartessa, Taiteen kaupungissa (www.unidee.it).

Toinen, yhtä ohjelmallinen, mutta löyhemmin or- ganisoitu esimerkki on kahden tanskalaistaiteilijan vuosina 2001-07 asunnossaan ylläpitämä Copenhagen Free University (CFU). Kyse oli sosiaalisesta tutkimuksesta ja kokeesta, jolla he halusivat osoittaa, että kuka tahansa voi perustaa oman yliopiston ja että yliopisto voidaan rakentaa arkipäivän kokemusten ympärille itseohjautuvasti (www.copenhagenfreeuniversity.dk/).

15. Nykytaiteen museo Kiasman Ars 06 -näyttelystä tehdyn tutkimuksen mukaan näyttelyvieraiden taideteosten vastaanottoa kuvailtiin shoppailuun rinnastettavana toimintana: epämiellyttävät tai vähemmän kiinnostavat taideteokset sivuutettiin suoraan, miellyttäviä tai puhuttelevia teoksia katsottiin kauemmin. Teosten merkityksillä myös leikiteltiin; erilaisissa mielentiloissa ja eri vierailukertoina näyttelyä ja teoksia tarkasteltiin eri tavoin. Merkitykset vaihtelivat - ei persoonakohtaisesti - vaan tilannekohtaisesti. (Rautio 2006.)

16. Seurallisuudesta enemmän, ks. Georg Simmel (1964 (1950), 31-33; 40-55).

Simmel luonnehti yhteiskunnan sosiaalisia muotoja esteettisinä. Hän oli kiinnostunut sosiaalisesta pinnasta ja sen estetiikasta; siitä, miten sosiaalinen kanssakäyminen on muotona kaunista ja miten se tuottaa siihen osallistuville mielihyvää. 